\title{
Analisis Tingkat Efisiensi Bank Umum Syariah di Indonesia pada Era Masyarakat Ekonomi Asean (MEA)
}

\author{
Analysis of Islamic bank efficiency in Indonesia for Asean Economic Community (AEC) \\ era
}

\section{Rona Rosida}

Program Studi D4 Keuangan Syariah, Politeknik Negeri Bandung

E-mail: rona.rosida.ksy16@polban.ac.id

\section{Dadang Hermawan}

Jurusan Akuntansi, Politeknik Negeri Bandung

E-mail: dadhar09@yahoo.com

\begin{abstract}
The purpose of this research is to identify the level of efficiency of Sharia Commercial Banks in the ASEAN Economic Community (AEC) era and also to identify the policies that can be taken by Sharia Commercial Banks to improve their efficiency by using the DE $A$ method and VRS model with an intermediation approach. Furthermore, this research uses 6 Sharia Foreign Exchange Commercial Banks as samples. This research shows that the average Sharia Commercial Bank has been quite efficient in carrying out its role as an intermediary institution. Sharia Commercial Banks that experience fluctuations in their efficiency are BNIS and BRIS. Whereas other Sharia Commercial Banks have consistently achieved optimum efficiency. Policy recommendations that can be implemented by Sharia Commercial Banks, especially for Sharia Commercial Banks that have not yet reached the optimum level of efficiency, to increase their level of efficiency are by controlling and allocating optimal resources and by further increasing their output capacity by maintaining existing inputs.
\end{abstract}

Keywords: Sharia Commercial Bank, Efficiency, Data Envelopment Analysis

\section{Pendahuluan}

Sejalan dengan disahkannya Blueprint ketiga Pilar Masyarakat ASEAN 2025, yaitu salah satunya Masyarakat Ekonomi ASEAN pada deklarasi Kuala Lumpur mengenai ASEAN 2025: Melangkah Maju Bersama sebagai ganti dari Roadmap Masyarakat ASEAN 2015 yang telah berakhir pada akhir 2015, maka salah satu sektor industri yang akan terpengaruh dengan terbukanya pintu gerbang Masyarakat Ekonomi ASEAN ini adalah industri perbankan. Selain itu, sektor perbankan juga tentunya menjadi salah satu peranan aktif dalam jalannya Masyarakat Ekonomi ASEAN, karena perbankan merupakan salah satu komponen utama dari sistem perekonomian sebagai lembaga intermediasi (Soemitra, 2015). Hal tersebut menuntut perbankan untuk terus meningkatkan dan mempertahankan ketahanan, daya saing, dan efisiensi dalam menghadapi segala tantangan di era Masyarkat Ekonomi ASEAN, termasuk Bank Umum Syariah di dalamnya.

Indonesia sebagai selah satu negara yang menjalankan dan mengembangkan industri perbankan syariah tentunya menjadi suatu pasar yang sangat menarik. Seperti yang dikatakan dalam Global Islamic Finance Report (2019) Indonesia sebagai negara dengan mayoritas muslim dan terbesar di dunia, yaitu lebih dari 207 juta jiwa atau sekitar 87,2\% dari total populasi, dan ditambah dengan adanya dukungan dari pemerintah, membuat Indonesia dapat menjadi pemimpin global dalam 
pasar keuangan syariah. Hal tersebut tentunya merupakan hal yang sangat baik bagi Indonesia dan dapat menjadi salah satu strategi yang dapat diambil dalam menghadapi Masyarakat Ekonomi ASEAN. Terbukti dengan pencapaian perbankan dan keungan syariah yang meraih peringkat pertama dalam Global Islamic Finance Report 2019, yang mengalahkan salah satu anggota dari ASEAN, yaitu Malaysia yang sebelumnya berada di peringkat pertama selama tiga tahun berturutturut (GIFR, 2019). Hal itu memberikan peluang yang sangat besar bagi Indonesia khususnya perbankan syariah dan dapat menjadi salah satu strategi Indonesia sebagai negara yang unggul di ASEAN maupun dunia.

Pada tahun pertama dilaksanakan MEA 2025, terlihat dari Gambar 1 pertumbuhan perbankan syariah mengalami peningkatan yang cukup tinggi, walupun di kuartal pertama mengalami kenaikan yang sangat sedikit, bahkan terlihat tidak ada peningkatan, dan peningkatan yang tinggi tersebut di mulai pada kuartal ke-II, sehingga pada akhir tahun 2016 meningkat sekitar $21 \%$. Sedangkan di tahun-tahun selanjutnya laju peningkatan aset perbankan syariah mengalami perlambatan, dibandingkan tahun-tahun sebelumnya, yaitu dibawah 15\%. Namun walaupun laju pertumbuhan perbankan melambat, pertubuhannya tetap menunjukan tren yang positif.

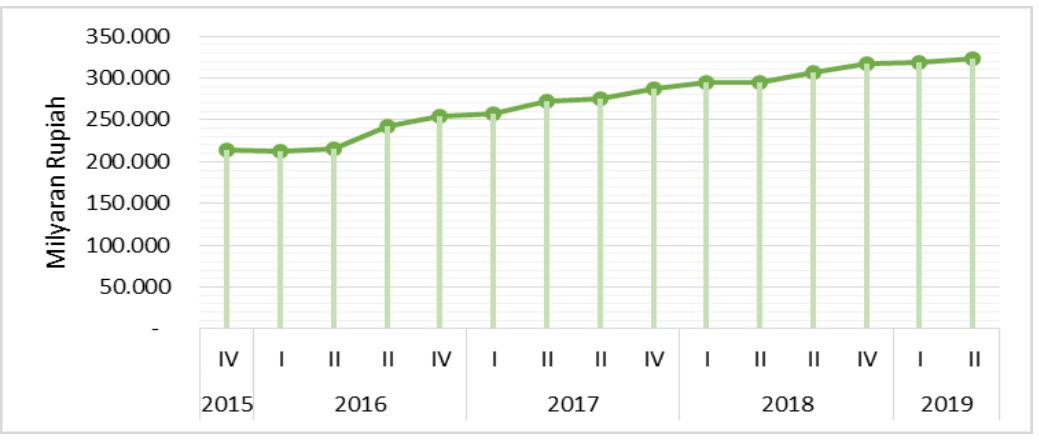

Gambar 1. Perkembangan Total Aset Bank Umum Syariah 2015 - 2019 (Statistik Perbankan Indonesia, 2015 - 2019)

Seperti dilansir dari bisnis.com, Direktur Pengaturan dan Perizinan Perbankan Syariah OJK Deden Firman Hendarsyah mengatakan bahwa salah satu yang penyebabkan melambatnya pertumbuhan aset perbankan syariah adalah karena sulitnya mencari nasabah pembiayaan. Dapat diihat pada Gambar 2 yang menunjukan rasio pembiayaan terhadap pendanaan, yaitu FDR cenderung mengalami penurunan. Penurunan rasio ini menunjukan banyaknya dana bank syariah yang tidak disalurkan kedalam pembiayaan. Dengan adanya pelambatan pertumbuhan dan nilai FDR yang cenderung menurun ini, membuat rasio profitabilitas bank syariah pun ikut melambat. Namun jika dilihat dari nilai NPF dan BOPO, bank syariah dari awal terbukanya pintu MEA ini, mengelami penurunan yang tentunya memiliki arti yang baik bagi bank syariah.

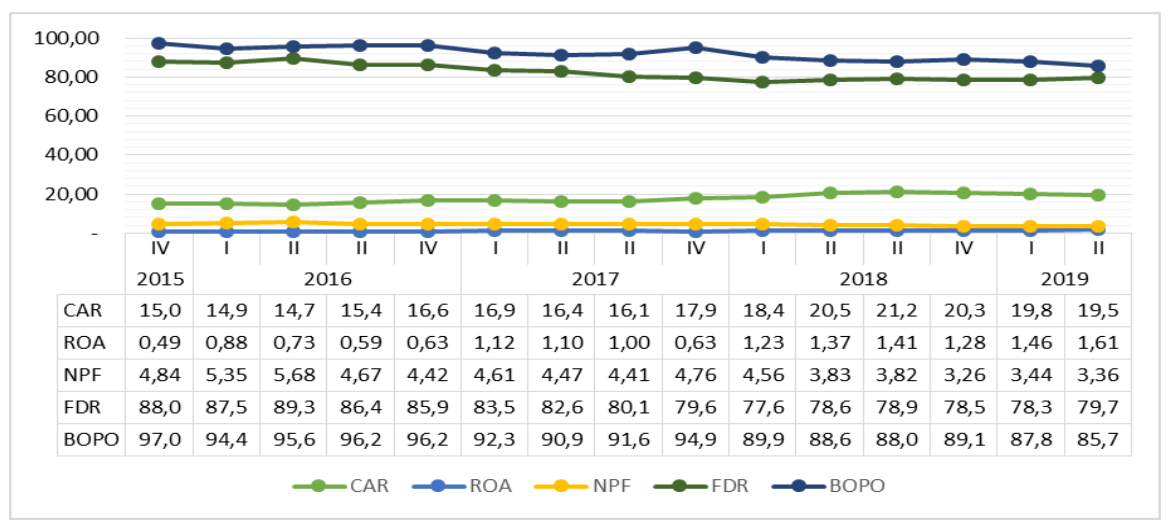

Gambar 2. Perkembangan Kenerja Perbankan 2015 - 2019 (Statistik Perbankan Indonesia, 2015 - 2019) 
Berbagai kondisi yang terjadi tersebut menjadi tantangan bagi bank syariah yang ada di Indonesia. Untuk dapat tetap bertahan dan bersaing maka diperlukan sebuah evaluasi terhadap kinerja, salah satunya dengan melihat efisiensi sehingga dapat menyusun strategi yang diperlukan untuk menghadapai segala tantangan yang ada (Solihin et al., 2016). Efisiensi merupakan suatu hal yang penting bagi dunia perbankan dalam melihat kemampuan bank dalam menggunakan input yang ada untuk menghasil output yang maksimal agar dapat mampu bertahan dan menghadapi persaingan dalam industri perbankan (Setyowati, 2019). Jika bank memiliki efisiensi yang baik, maka dapat meningkatkan reputasi bank tersebut di mata para stakeholder (Hijriyani \& Setiawan, 2017). Selain itu, dengan efisiensi yang baik bank dapat meningkatkan keuntungannya dengan optimal, mampu menyalurkan lebih banyak dana, dapat menawarkan tingkat harga, kualitas jasa, dan keamanaan yang lebih baik, serta dapat meningkatkan kesejahteraan ekonomi secara menyeluruh (Karimah et al., 2016). Sehingga bank yang efisien tentunya akan lebih unggul dari bank yang belum efisien.

Berdasarkan pemaparan latar belakang di atas, maka rumusan masalah dari penelitian ini adalah 1. Bagaimana tingkat efisiensi yang dicapai Bank Umum Syariah di Indonesia pada era Masyarakat Ekonomi ASEAN (MEA) selama periode 2016 - 2019 dengan metode Data Envelopment Analysis (DEA)? 2. Bagaimana kebijakan yang dapat dilakukan Bank Umum Syariah dalam meningkatkan efisiensinya berdasarkan hasil dari metode Data Envelopment Analysis (DEA) periode tahun 2016 - 2019?

\section{Kajian Pustaka}

\subsection{Konsep Efisiensi}

Konsep efisiensi berasal dari konsep mikro ekonomi yaitu teori produsen, yang mencoba untuk memaksimumkan keuntungan atau meminimumkan biaya dari sudut pandang produsen. Pada teori produsen tersebut terdapat kurva batas produksi (production frontier curve) yang menggambarkan hubungan antaran nput dan output dari prosess produksi. Kurva frontier produksi ini mewakili tingkat output maksimum dari setiap penggunaan input yang mewakili penggunaan teknologi dari suatu perusahaan atau industri (Ascarya \& Yumanita dalam Rusydiana, 2019).

Menurut Adrian dan Lestari dalam Puteh et al. (2018), konsep efisiensi secara umum, dapat diarahkan pada konsep pencapaian hasil dengan penggunaan sumber daya yang optimal. Dalam teori ekonomie, terdapat dua konsep umum efisiensi, yaitu efisiensi dalam hal konsep ekonomi dan konsep produksi. Efisiensi dalam konsep ekonomi memiliki ruang lingkup yang lebih luas dalam hal perspektif makro, sedangkan efisiensi dalam konsep produksi dilihat dari perspektif mikro.

Efisiensi menurut KBBI adalah ketepatan cara atau kemampuan dalam menjalankan sesuatu dengan tidak membuang waktu, tenaga, dan biaya atau dengan baik dan tepat. Menurut Noor dalam Puspitasari et al. (2018), Efisiensi adalah istilah yang diigunakan untuk menggukur kemampuan pengelolaan atau pemanfaatan asset produksi. Semakin mendekati ideal, dikatakan semakin efisien, dan sebaliknya. Oleh Karena itu efisiensi ini berkaitan dengan rantai nilai (value chain), yaitu hubungan antar aktifitas yang dilakukan dalam menciptakan barang dan jasa.

Sedangkan menurut Farrell dalam Rusydiana (2019), efisiensi dari perusahaan terdiri dari dua komponen, yaitu efisiensi teknis dan efiseinsi alokatif. Efiseinsi teknis menggambarkan kemampuan dari perusahaan dalm menghasilkan output dengan sejumlah input yang tersedia. Sedangkan efiseinsi alokatif menggambarkan kemampuan perusahaan dalam mengoptimalkan penggunaan input dengan struktur harga dan teknologi produksi. 


\subsection{Pengukuran Efisiensi Perbankan}

Terdapat tiga jenis pendekatan pengukuran efisiensi khususnya dalam perbankan, menurut Muharam dan Pusvitasari dalam jurnal Kusumo \& Karim (2017), yaitu:

a. Pendekatan Rasio, yaitu pendekatan yang mengukur efisiensi dilakukan dengan cara menghitung perbandingan output dan input yang digunakan. Pendekatan ini akan dapat dinilai mempunyai efisiensi yang tinggi apabila dapat menghasilkan output yanng semaksimal mungkin dengan input yang seminimal mungkin. Kelemahan pedekatan ini yaitu apabila terdapat banyak input dan banyak output yang akan dihitung bersamaan, maka akan menghasilkan asumsivyang kurang tegas.

b. Pendekatan Regresi, yaitu pendekatan yang mengukur efisiensi dengan menggunakan sebuah model dari tingkat output tertentu sebagai fungsi dari berbagai tingkat input tertentu, dengan menghasilkan etimasi hubungan yang daapat digunakan untuk memproduksi tingkat outpuut yang dihasilkan sebua unit kegiatan ekonomi pada tingkat input tertentu. Unit kegiatan ekonomi dapat dikatakan efisien apabila menghasilkan output lebih banyak dari pada output hasil esttimasi. Kelemahan dalam pendekatan ini adalah tidak dapat menghimpun banyak output, karena dalam sebuah persamaan regresi hanya dapat menampung satu indikator output. Apabila dilakukan penggabungan banyak output dalam satu indikator maka informasi yang didapatkan menjadi tidak rinci lagi.

c. Pendekatan Frontier, yaitu pendekatan membedakan dalam mengukur efisiensi menjadi dua jenis yaitu pendekatan parametrik dan non parametrik. Tes parametrik adalah tes yang modelnya menetapkan adanya syarat-syarat tertentu tentang parameter populasi yang merupakan sumber penelitiannya, sedangkan tes non parametrik adalah tes yang modelnya tidak menetapkan syarat-syarat perihal parameter populasi yang merupakan induk sampel penelitiannya. Pendekatan parametrik dapat diukur dengan mengunakan metode seperti Stochastic Frontier Analysis (SFA) dan Distribution Free Analysis (DFA). Sedangkan pendekatan non parametrik dapat diukur dengan dengan menggunakan metode seperti Data Envelopment Analysis (DEA).

\subsection{Konsep Data Envelopment Analysis (DEA)}

Data Envelopment Analysis (DEA) adalah teknik program linear untuk mengukur tingkat efisiensi suatu Decision Making Unit (DMU) atau unit pengambilan keputusan (UPK), pada suatu perusahaan sebagai tolak ukur dan evaluasi dalam membuat suatu keputusan, yang dikembangkan pertama kali oleh Charnes, Cooper dan Rhodes pada tahun 1978 (Fauziah et al., 2019).

Data Envelopment Analysis (DEA) menurut Tanjung \& Devi (2018) adalah analisis inti yang digunakan oleh analisis frontier, yang di dalamnya terdapat beragam fitur ekstra seperti analisis regresi, sehinga dapat memberikan kemudahan untuk membuat penelitian terkait efisiensi dan menyediakan alat analisis efisiensi yang komperehensif, yang bertujuan untuk menilai efisiensi pada suatu unit operasional, melalui perhitungan nilai efisienis dari setiap unit dalam suatu kumpulan data.

Teknik perhitungan dalam metodologi Data Envelopment Analysis (DEA) berdasarkan solusi dari program linier. Metode ini meyediakan perbandingan yang tajam dan dapat digunakan untuk mengidentifikasi suatu unit bisnis yang memiliki performa paling bagus untuk dijadikan rujukan dan unit bisnis yang berada di bwah prestasi sehingga memungkinkan untuk dipertahankan atau dibuang melalu perhitungan perbandingan rasio output dan input untuk semua unit yang dibandingkan. Jika suatu unit bisnis ditemukan tidak efisien, maka akan mengidentifikasikan bagaimana sumber daya yang dapat dialokasikan lebih efektif dalam rangkan meningkatkan efisiensi. Dikarenakan Data Envelopment Analysis (DEA) melakukan perbandingan yang tajam (Tanjung \& Devi, 2018). 
Menurut Kamarudin et al. (2019), Data Envelopment Analysis (DEA) merupakan pendekatan utama yang biasanya disukai oleh peneliti untuk analisis kinerja industri perbankan karena memungkinkan tingkat efisiensi berubah dari waktu ke waktu dan tidak perlu asumsi sebelumny mengenai speksifikasi perbatasan praktik terbaik.

\subsection{Model-Model DEA}

Dalam mengaplikasikan metode DEA menurut Tanjung \& Devi (2018), terdapat 2 (dua) jenis model pengukuran efisiensi yang digunakan untuk menganalisis efisiensi unit kegiatan ekonomi, yaitu :

1. Constant Return to Scale (CRS), diperkenalkan pertama kali oleh Charnes, Cooper dan Rhodes pada tahun 1978. Dalam model CRS setiap perusahaan atau Decision Making Unit (DMU) yang akan diukur tingkat efisiensinya akan dibandingkan dengan seluruh DMU yang ada di sampel dengan asumsi bahwa kondisi internal dan eksternal perusahaan adalah sama. Model CRS mengasumsikan bahwa rasio antara penambahan input dan output adalah sama (constant return to scale), artinya jika ada penambahan input sebesar x kali, maka output akan meningkat sebesar $\mathrm{x}$ kali juga. Asumsi lain yang digunakan dalam model ini adalah bahwa setiap perusahaan atau DMU beroperasi secara optimal.

2. Variabel Return to Scale (VRS) merupakan pengembangan dari model CCR yang diperkenalkan oleh Banker, Charnes, dan Cooper (BCC) pada tahun 1984. Model VSR mengasumsikan bahwa rasio antara penambahan input dan output tidak sama. Artinya apabila ada penambahan input $\mathrm{X} \%$ tidak menyebabkan penambahan pada output $\mathrm{X} \%$ juga bisa jadi lebih besar atau lebih kecil. Dan dapat dikatakan bahwa tidak semua kegiatan unit ekonomi beroperasi secara optimal. Kendala keuangan, persaingan tidak sempurna, dan sebagainya, dapat menyebabkan perusahaan tidak beroperasi secara optimal. Pendekatan ini relatif tepat digunakan dalam menganalisis efisiensi kinerja pada perusahaan jasa termasuk bank. Variable return to scale merupakan asumsi yang lebih tepat digunakan untuk sampel yang besar.

\subsection{Kelebihan dan Kelemahan DEA}

Dalam perkembangannya, metode DEA tentunya memiliki kelebihan dan kekurangannya, dalam konteks pengukuran efisiensi sebuah industri. Berdarkan yang diungapkan oleh Tanjung \& Devi (2018) dalam bukunya yang bejudul Meteologi Penelitian Ekonomi Islam, kelebihan dari penggunaan metode ini diantaranya adalah mampu menangani pengukuran efisiensi dengan menggunaan beragai input dan output sebagai landasan pengukuran, tidak mebutuhkan asumsi hubungan fungsional antara variabel input dan output, Decision Making Unit (DMU) dibandingkan secara langsung dengan sesamanya, dan dapat menggunakan variabel dengan satuan yang berbeda. Sedangkan kelemahan dari metode ini menurut Tanjung \& Devi (2018) adalah dapat menyebabkan pada masalah yang cukup signifikan apabila terjadi kesalahan pada pengukuran, hanya dapat mengukur efisiensi relatif dari unit-unit yang diamati dan tidak mengukur efisiensi absolut, uji hipotesis secara statistik sulit dilakukan, dan sulit dilakukan dan membutuhkan waktu yang tidak sebentar jika dihitung secara manual.

\subsection{Hubungan Variabel Input-Output}

Tingkat efisiensi sangat ditentukan oleh pemilihan variabel-variabel yang menjadi input dan output. Belum ada kesepakatan dalam literatur perbankan dalam hal pengdefinisian input dan output perbankan. Setidaknya terdap Setidaknya Menurut Benston dkk dalam Solihin et al. (2016), terdapat tiga sudut pandang dalam hal pendefinisian input dan output perbankan, yaitu ekonom melihat output bank sebagai nilai nominal dari deposit dan financing, ahli moneter melihat bank sebagai pencipta money demand, dan sisanya melihat bank sebagai produsen financing dengan deposito sebagai bahan mentahnya (input). 
Menurut Hadad dkk dalam Puspitasari et al. (2018), ada 3 (tiga) pendekatan yang digunakan dalam mendefinisikan hubungan input dan output dalam tingkah laku dari lembaga keuangan. Pendekatan yang digunakan dalam mendefinisikan hubungan input dan output, yaitu:

1. Pendekatan Produksi (The Production Approach), yaitu pendekatan yang menganggap lembaga keuangan sebagai produsen dari akun deposito (deposits account) dan akun pinjaman (credit account). Dalam pendekatan ini output didefinisikan sebagai jumlah tenaga kerja, pengeluaran modal pada aktiva tetap dan material lainnya

2. Pendekatan Aset (The Assets Approach), yaitu pendekatan yang menganggap lembaga keungan sebagai pencipta penjaman (loans) dan diukur berdasarkan kemampuan perbankan menanamkan dana dalam bentuk pinjaman/pembiayaan atau aset lainnya sebagai output. Sedangkan input diukur dari biaya-biaya.

3. Pendekatan Intermediasi (Intermediation Approach), yaitu pendekatan yang memandang sebuah lembaga keuangan sebagai perantara atau internnediator, yaitu mengubah atau mentransfer aset-aset keuangan dari unit-unit yang kelebihan dana (surplus unit) keunitunit yang kekurangan dana (deficit unit). Dalam pendekatan ini yang termasuk input seperti modal dan biaya tenaga kerja, lalu pengukuran output dalam bentuk kredit pinjaman (loans) dan investasi keuangan (financial investment).

Konsekuensi dari adanya tiga pendekatan ini, yaitu terdapatnya perbedaan dalam menentukan variabel input dan output, khususnya pada pendekatan produksi dan pendekatan intermediasi dalam memperlakukan simpanan. Dalam pendekatan produksi, simpanan diperlakukan sebagai output, karena simpanan merupakan jasa yang dihasilkan melalui kegiatan bank. Sedangkan dalam pendekatan intermediasi simpanan ditempatkan sebagai input, karena simpanan yang dihimpun bank akan mentransformasikannya ke dalam bentuk aset yang menghasilkan, terutama pinjaman yang diberikan.

\section{Metode Penelitian}

Penelitian ini menggunakan metode penelitian deskriptif kuantitatif. Dengan jenis data berupa data panel dan dengan menggunakan data sekunder yang diperoleh dari laporan keuangan triwulan yang dipublikasikan di website Otoritas Jasa Keuangan (OJK) dan website masing-masing Bank Umum Syariah yang menjadi sampel dalam penelitian ini selama periode kuartal I 2016 sampai dengan periode kuartal II 2019 dan selanjutnya dilakukan pengumpulan pustaka dengan mengkaji beberapa jurnal, buku literatur, dokumen, dan artikel untuk memperoleh landasan teori, dan menjawab permasalah tentang kinerja efisiensi bank umum syariah.

Populasi dalam penelitian ini adalah Bank Umum syariah yang terdaftar di Bank Indonesia dan Otoritas Jasa Keuangan. Sedangkan dalam pengambilan sampel dalam penelitian ini menggunakan teknik purposive sampling, dengan kriteria, yaitu Bank Umum Syariah yang beroperasi di Indonesia pada tahun 2016 sampai 2019 yang dapat melakukan kegaitan usaha perbankan dalam valuta asing (Bank Umum Syariah Devisa), menyajikan laporan keuangan triwulanan secara lengkap selama periode pengamatan yaitu Kuartal I 2016 sampai Kuartal II 2019 dan telah dipublikasikan oleh Otoritas Jasa Keuangan dan website masing-masing bank yang bersangkutan, dan tidak memiliki nilai atau bobot negatif pada variabel input dan output dalam laporan keuangan Bank Umum Syariah yang merupakan syarat analisis efisiensi dengan menggunakan metode DEA. Berdasarkan kriteria tersebut maka terdapat 6 Bank Umum Syariah, yaitu Bank Muamalat indonesia, Bank Mega Syariah, BNI Syariah, BRI Syariah, Bank Syariah Mandiri, dan Bank Panin Dubai syariah. 
Dalam pengukuran tingkat efisiensi dalam penelitian ini menggunakan perangkat aplikasi Banxia Frontier Analysis dan Microsoft Excel, sebagai perangkat pendukung, tanpa melakukan perhitungan manual. Tujuan dari penelitiankini untuk menganalisis tingkat efisiensi Bank Umum Syariah dan strateginya dalam meningkatkan efisiensi tersebut dalam menghadapi Masyarakat Ekonomi ASEAN (MEA). Penelitiian efisiensi Bank Umum Syariahmini menggunakan metode Data Envelopment Analysis (DEA) dengan model Variable Returnnto Scale (VRS). Sedangkan pada penentuan variabel input dan outputnya, penelitian ini menggunakan pendekatan intermediasi. Variabel-variabel yang digunakan dalam penelitian ini, yaitu Dana Pihak Ketiga (DPK), Biaya Tenaga Kerja, dan Aset, yang merupakan variabel inputnya, sedangkan variabel outputnya adalah Total Pembiayaan dan Pendapatan Operasional.

\section{Hasil dan Pembahasan}

\subsection{Tingkat Efisiensi Bank Umum Syariah di Indonesia}

Berdasarkan hasil perhitungan Data Envelopment Analysis (DEA) dengan model Variable Return to Scale (VRS) menggunakan bantuan aplikasi Banxia Frontier Analysis, dapat dilihat tingkat efisiensi enam Bank Umum Syariah selama periode penelitian kuartal I 2016 sampai kuartal II 2019, yaitu sebagai berikut :

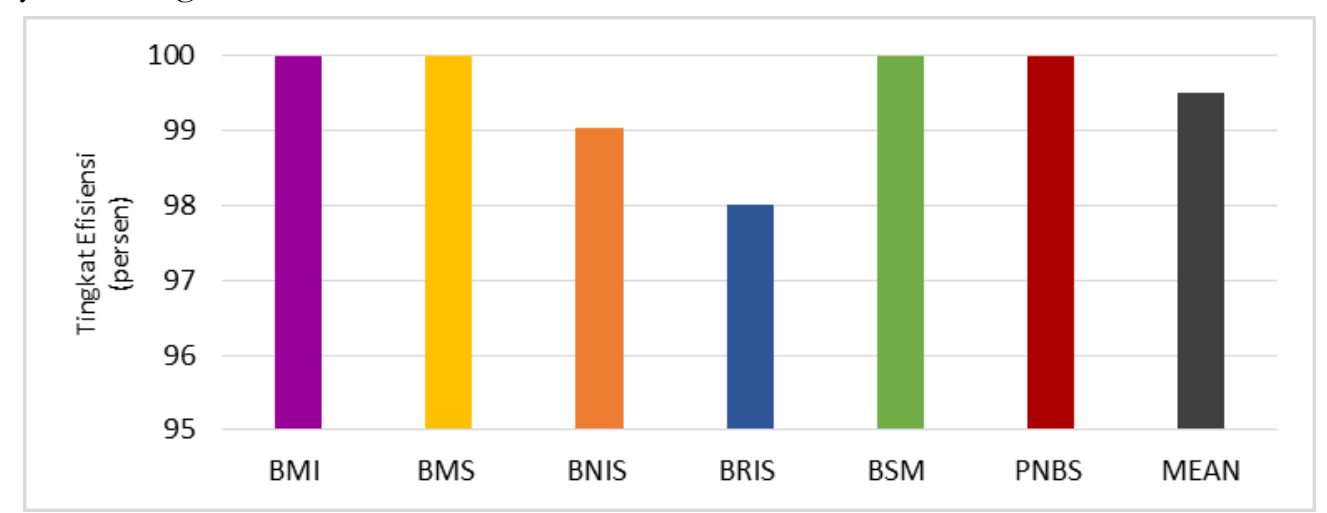

Gambar 3. Rata-Rata Tingkat Efisiensi Bank Umum Syariah Kuartal I 2016 - Kuartal II 2019

Dapat dilihat Gambar 3 diatas menunjukan bahwa selama periode penelitian mulai dari kuartal I 2016 sampai dengan kuartal II 2019 rata-rata keseluruhan tingkat efisiensi enam Bank Umum Syariah di Indonesia yaitu sebesar 99,15\%. Hasil tersebut menunjukan bahwa tingkat efisiensi Bank Umum Syariah di Indonesia yang dapat melakukan transaksi keluar negeri atau segala yang berhubungan dengan mata uang asing sudah dikategorikan cukup baik dan hampir mencapai tingkat efisiensi optimum, yaitu 100\%. Artinya sebagian besar Bank Umum Syariah selama periode penelitian telah cukup baik dalam menjalankan perannya sebagai lembaga intermediasi. Dalam Gambar diatas juga terlihat bahwa selama periode penelitian hanya dua Bank Umum Syariah yang belum mencapai tingkat efisiensi optimum, yaitu Bank Negara Indonesia Syariah (BNIS) dan Bank Rakyat Indonesia Syariah (BRIS). Sedangkan Bank Umum Syariah lainnya telah mencapai tingkat efisiensi optimum selama periode penelitian ini. Hal tersebut yang mengakibatkan rata-rata keseluruhan tingkat efisiensi Bank Umum Syariah belum mencapai tingkat efisiensi optimum. Hal tersebut juga yang mengindikasi bahwa Bank Umum Syariah secara keseluruhan cukup baik dalam tingkat efisiensinya, karena cukup banyaknya Bank Umum Syariah yang telah mencapai efisiensi optimumnya.

Untuk lebih jelasnya mengenai keadaan tingkat efisiensi Bank Umum Syariah pada setiap periode penelitan dapat dilihat pada Gambar 4 berikut : 


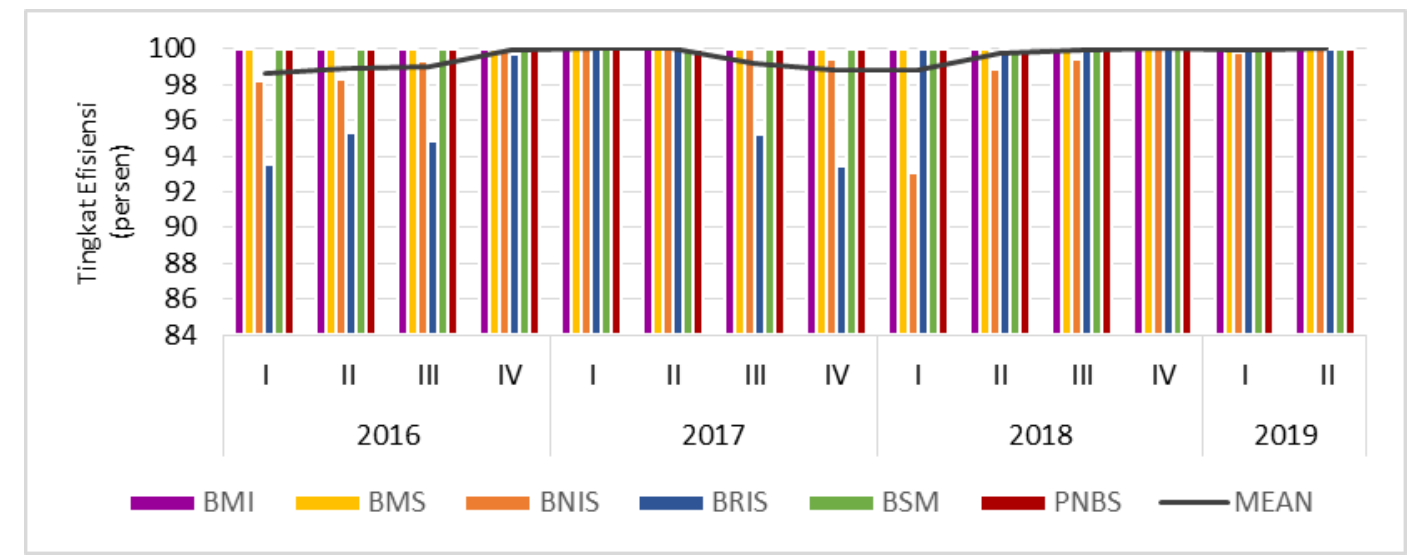

Gambar 4. Tingkat Efisiensi Bank Umum Syariah

Kuartal I 2016 - Kuartal II 2019

Berdasarkan Gambar 4 tersebut yang menggambarkan percapaian nilai tingkat efisiensi setiap periodenya, rata-rata tingkat efisiensi pada Bank Umum Syariah yang menjadi objek dalam penelitian ini mengalami fluktuasi yang relatif kecil dengan nilai yang hampir mencapai tingkat efisiensi optimum. Sepanjang periode penelitian mulai dari kuartal I 2016 sampai dengan kuartal II 2019, Bank Umum Syariah yang selalu mencapai tingkat efisiensi optimum dengan nilai sebesar 100\% secara konsisten atau berturut-turut adalah Bank Muamalat Indonesia (BMI), Bank Mega Syariah (BMS), Bank Syariah Mandiri (BSM), dan Bank Panin Dubai Syariah (PNBS). Sedangkan Bank Umum Syariah yang mengalami fluktuasi pada tingkat efisiensinya adalah Bank Negara Indonesia Syariah (BNIS) dan Bank Rakyat Indonesia Syariah (BRIS), dengan nilai efisiensi terendah dimiliki oleh Bank Negara Indonesia (BNIS), yaitu sebensar 93.09\%.

Dapat dilihat juga pada Gambar 4, pada tahun 2016 yang merupakan tahun pertama dilaksanakan MEA 2015, pada periode kuartal I, II, dan III, Bank Negara Indonesia Syariah (BNIS) dan Bank Rakyat Indonesia Syariah (BRIS) mendapatkan tingkat efisiensi dibawah nilai efisiensi optimum, sedangkan nilai terendah didapatkan oleh Bank Rakyat Indonesia Syariah (BRIS) secara berturut-turut dengan terus mengalami peningkatan sehingga pada periode IV akhirnya Bank Negara Indonesia Syariah (BNIS) dapat mencapai tingkat efisiensi optimum, sedangakan Rakyat Indonesia Syariah (BRIS) masih belum mencapai tingkat efisiensi optimum juga. Lalu pada tahun 2017 periode kuartal I dan II, menjadi periode yang paling efisien karena semua Bank Umum Syariah mendapatkan tingkat efisien optimum. Lalu pada periode II Bank Rakyat Indonesia Syariah (BRIS) kembali mengalami penurunan hingga pada kuartal IV dan diikut oleh Bank Negara Indonesia Syariah (BNIS) yang kambali tidak efisiesn pada kuartal IV, dengan nilai terendah didapat oleh Rakyat Indonesia Syariah (BRIS). Sedangakan Pada tahun 2018, selama periode kuartal I sampai dengan III, Bank Negara Indonesia Syariah (BNIS) terus mendapatkan tingkat efisiensi dibawah nilai efisiensi optimum dan kembali membaik pada kuartal IV. Dan pada tahun 2019 di kuartal I, Bank Negara Indonesia Syariah (BNIS) lagi-lagi mendapatkan tingkat efisiensi dibawah nilai efisiensi optimum, namun pada kuartal II, Bank Negara Indonesia Syariah (BNIS) kembali mendapatkan tingkat efisensi optimum sehingga pada kuartal II yang merupakan periode terakhir dalam penelitian ini kembali menjadi periode yang paling efisien dengan tingkat efisiensi optimum yang dicapaii oleh semua Bank Umum Syariah.

Selain mengetahui tingkat efisiensi, keunggulan dari metode Data Envelopment Analysis (DEA) adalah dapat menunjukan kontribusi pencaapaian masing-masing variable input maupun output yang diimiliki oleh unit yang dianalisis dalam membentuk sebuah nilai tingkat efisiensinya. Seperti pada Bank Mumalat Indonesia (BMI), Bank Mega Syariah (BMS), Bank Syariah Mandiri (BSM), dan Bank Panin Dubai Syariah (PNBS), sepanjang periode penelitian telah mencapai tingkat 
efisiensi optimum sehingga setiap variabel input dan outputnya telah berkontribusi secara maksimal dalam membentuk tingkat efisiensinya. Sedangkan Bank Umum Syariah yang belum dapat mencapai tingkat efisiensi optimum terjadi karena adanya variabel input ataupun output yang belum berkontribusi secara maksimal dalam mencapai tingkat efisiensi optimum pada masingmasing Bank Umum Syariah selama periode penelitian. Hal tersebut dapat menjadi salah satu bahan evaluasi dan perbaikan yang dapat dilakukan oleh Bank Umum Syariah. Hal yang mengalami hal tersebut, yaitu Bank Negara Indonesia Syariah (BRIS) dan Bank Rakyat Indonesia Syariah (BRIS).

Berikut merupakan tingkat efisiensi dari Bank Negara Indonesia Syariah (BNIS) berserta kontribusi veriabel input dan output nya selama periode penelitian yaitu mulai dari kuartal I 2016 sampai dengan kuartal II 2019.

Tabel. 1 Tingkat Efisiensi Bank Negara Indonesia Syariah (BNIS)

Kuartal I 2016 - Kuartal II 2019

\begin{tabular}{|c|c|c|c|c|c|c|c|}
\hline \multirow{2}{*}{\multicolumn{2}{|c|}{ Periode }} & \multirow{3}{*}{$\begin{array}{c}\begin{array}{c}\text { Tingkat } \\
\text { Efisiensi }\end{array} \\
98,21 \%\end{array}$} & \multicolumn{3}{|c|}{ Input } & \multicolumn{2}{|c|}{ Output } \\
\hline & & & \multirow{2}{*}{$\frac{\text { DPK }}{90,5 \%}$} & \multirow{2}{*}{$\frac{\text { BTK }}{79,2 \%}$} & \multirow{2}{*}{$\begin{array}{l}\text { ASET } \\
100 \%\end{array}$} & \multirow{2}{*}{\begin{tabular}{|c|} 
PEMBIA YAAN \\
$98,2 \%$
\end{tabular}} & \multirow{2}{*}{$\frac{\text { PEND OPR }}{98,2 \%}$} \\
\hline \multirow{4}{*}{2016} & $\mathrm{I}$ & & & & & & \\
\hline & II & $98,35 \%$ & $90,4 \%$ & $73,5 \%$ & $100 \%$ & $98,3 \%$ & $98,3 \%$ \\
\hline & III & $99,32 \%$ & $95,5 \%$ & $78 \%$ & $100 \%$ & $99,3 \%$ & $99,3 \%$ \\
\hline & IV & $100 \%$ & $100 \%$ & $100 \%$ & $100 \%$ & $100 \%$ & $100 \%$ \\
\hline \multirow{4}{*}{2017} & $\mathrm{I}$ & $100 \%$ & $100 \%$ & $100 \%$ & $100 \%$ & $100 \%$ & $100 \%$ \\
\hline & II & $100 \%$ & $100 \%$ & $100 \%$ & $100 \%$ & $100 \%$ & $100 \%$ \\
\hline & III & $100 \%$ & $100 \%$ & $100 \%$ & $100 \%$ & $100 \%$ & $100 \%$ \\
\hline & IV & $99,45 \%$ & $99,9 \%$ & $100 \%$ & $100 \%$ & $99,4 \%$ & $99,4 \%$ \\
\hline \multirow{4}{*}{2018} & $\mathrm{I}$ & $93,09 \%$ & $100 \%$ & $83,1 \%$ & $98,9 \%$ & $92,6 \%$ & $92,6 \%$ \\
\hline & II & $98,83 \%$ & $98,8 \%$ & $76,6 \%$ & $100 \%$ & $98,8 \%$ & $98,8 \%$ \\
\hline & III & $99,41 \%$ & $100 \%$ & $82,1 \%$ & $99,7 \%$ & $99,4 \%$ & $99,4 \%$ \\
\hline & IV & $100 \%$ & $100 \%$ & $100 \%$ & $100 \%$ & $100 \%$ & $100 \%$ \\
\hline \multirow{2}{*}{2019} & $\mathrm{I}$ & $99,79 \%$ & $99,4 \%$ & $85 \%$ & $100 \%$ & $95,1 \%$ & $99,8 \%$ \\
\hline & II & $100 \%$ & $100 \%$ & $100 \%$ & $100 \%$ & $100 \%$ & $100 \%$ \\
\hline \multicolumn{2}{|c|}{ Mean } & $99,03 \%$ & $98,18 \%$ & $89,82 \%$ & $99,90 \%$ & $98,65 \%$ & $98,99 \%$ \\
\hline
\end{tabular}

Berdasarkan pada Tabel 1 diatas, dapat dilihat bahwa tingkat efisiensi Bank Negara Indonesia Syariah (BNIS) selama periode penelitian, kuartal I 2016 sampai kuartal II 2019, mengalami fluktuatif dengan nilai rata-rata sebesar 99,03\%. Pada awal periode mulainya MEA 2025, kuartal I 2016 Bank Negara Indoneisa Syariah (BNIS) belum mencapai tingkat efisiensi optimum dengan nilai sebesar 98,21\%, lalu pada periode berikutnya kuartal II 2016 meningkat menjadi 98.35\%, dan kuartal III 2016 meningkat kembali menjadi 99,32\%, walaupun belum mencapai tingkat efisiensi optimum, dan pada akhirnya pada kuartal IV 2016 Bank Negara Indonesia Syariah (BNIS) mendapatkan nilai efisiensi optimum sampai dengan kuartal III 2017, hingga pada akhinya Bank Negara Indoneisa Syariah (BNIS) mengalami penurunan kembali pada periode berikutnya menjadi 99,45\% pada kuartal IV 2017, dan menurun kembali menjadi 93.09\% pada kuartal I 2018 yang merupakan periode dengan nilai efisiensi terendah yang didapatkan oleh Bank Negara Indoneisa Syariah (BNIS). Lalu pada periode selanjutnya terus mengalami peningkat kembali pada kuartal II 2018 menjadi 98.83\% serta pada kuartal III 2018 menjadi 99,41\%, dan pada kuartal IV 2018 akhirnya kembali lagi mencapai tingkat efisiensi optimum. Namun sayangnya pada kuartal I 2019 kembali lagi turun menjadi 99.79\%. Dan akhirnya pada periode terakhir penelitian Bank Negara Indonesia Syariah (BNIS) kembali lagi mencapai tingkat efisiensi optimum.

Berdasarkan penjelasan diatas menunjukan bahwa selama periode penelitian, Bank Negara Indoneisa Syariah (BNIS) dari awal mulainya MEA 2025 dan di beberapa periode selanjutnya belum dapat menjalankan fungsinya sebagai lembaga intermediasi secara optimal dan efisien sebanyak delapan kali, namun juga di beberapa periodenya Bank Negara Indonesia Syariah (BNIS) telah menjalankan fungsinya sebagai lembaga intermediasi secara optimal dan efisien sebanyak enam kali.

Belum efisiennya Bank Negara Indonesia Syariah (BNIS), yaitu akibat dari adanya varibel input maupun output yang belum berkontribusi secara maksimal dalam mencapai tingkat efisiensi 
optimumnya. Pada kuartal I 2016 sampai dengan kuartal III 2016, kuartal II 2018, dan kuartal I 2019 mengalami penyebab yang sama, yaitu akibat dari adanya peningkatan pada Dana Pihak Ketiga (DPK) dan pemborosan pada Biaya Tenaga Kerja (BTK) yang tidak sebanding dengan peningkatan pada jumlah Pembiayaan dan Pendapatan Operasional yang dihasilkan. Sedangkan pada kuartal I 2018 dan kuartal III 2018, diakibatkan karena adanya pemborosan pada Biaya Tenaga Kerja yang dikeluarkan dan besarnya nilai Aset yang dimiliki tidak sebanding dengan peningkatan pada jumlah Pembiayaan dan Pendapatan Operasional yang didapat. Dan lalu penyebab pada kuartal IV 2018, yaitu akibat dari adanya peningkatan Dana Pihak Ketiga (DPK) yang tidak sebanding dengan peningkatan pada pembiayaan dan pendapatan operasionalnya.

Sedangkan berikut merupakan tingkat efisiensi yang dicapai oeleh Bank Rakyat Indonesia Syariah (BRIS) berserta kontribusi veriabel input dan output nya selama periode penelitian, kuartal I 2016 sampai dengan kuartal II 2019.

Tabel. 2 Tingkat Efisiensi Bank Rakyat Indonesia Syariah (BRIS) Kuartal I 2016 - Kuartal II 2019

\begin{tabular}{|c|c|c|c|c|c|c|c|}
\hline \multirow{2}{*}{\multicolumn{2}{|c|}{ Periode }} & \multirow{3}{*}{$\begin{array}{c}\begin{array}{c}\text { Tingkat } \\
\text { Efisiensi }\end{array} \\
93,55 \%\end{array}$} & \multicolumn{3}{|c|}{ Input } & \multicolumn{2}{|c|}{ Output } \\
\hline & & & \multirow{2}{*}{$\frac{\text { DPK }}{91,7 \%}$} & \multirow{2}{*}{$\frac{\text { BTK }}{75,7 \%}$} & \multirow{2}{*}{$\frac{\text { ASET }}{100 \%}$} & \multirow{2}{*}{\begin{tabular}{|c|} 
PEMBIA YAAN \\
$93,1 \%$
\end{tabular}} & \multirow{2}{*}{$\begin{array}{c}\text { PEND OPR } \\
93,1 \%\end{array}$} \\
\hline \multirow{4}{*}{2016} & I & & & & & & \\
\hline & II & $95,33 \%$ & $92,2 \%$ & $98,6 \%$ & $100 \%$ & $95,1 \%$ & $95,1 \%$ \\
\hline & III & $94,83 \%$ & $99,4 \%$ & $95,9 \%$ & $100 \%$ & $94,6 \%$ & $94,6 \%$ \\
\hline & IV & $99,72 \%$ & $100 \%$ & $100 \%$ & $99,4 \%$ & $90,1 \%$ & $99,7 \%$ \\
\hline \multirow{4}{*}{2017} & $\mathrm{I}$ & $100 \%$ & $100 \%$ & $100 \%$ & $100 \%$ & $100 \%$ & $100 \%$ \\
\hline & II & $100 \%$ & $100 \%$ & $100 \%$ & $100 \%$ & $100 \%$ & $100 \%$ \\
\hline & III & $95,2 \%$ & $100 \%$ & $100 \%$ & $97,9 \%$ & $87,8 \%$ & $95 \%$ \\
\hline & IV & $93,44 \%$ & $100 \%$ & $100 \%$ & $99,7 \%$ & $87,6 \%$ & $93 \%$ \\
\hline \multirow{4}{*}{2018} & $\mathrm{I}$ & $100 \%$ & $100 \%$ & $100 \%$ & $100 \%$ & $100 \%$ & $100 \%$ \\
\hline & II & $100 \%$ & $100 \%$ & $100 \%$ & $100 \%$ & $100 \%$ & $100 \%$ \\
\hline & III & $100 \%$ & $100 \%$ & $100 \%$ & $100 \%$ & $100 \%$ & $100 \%$ \\
\hline & IV & $100 \%$ & $100 \%$ & $100 \%$ & $100 \%$ & $100 \%$ & $100 \%$ \\
\hline \multirow{2}{*}{2019} & $\mathrm{I}$ & $100 \%$ & $100 \%$ & $100 \%$ & $100 \%$ & $100 \%$ & $100 \%$ \\
\hline & II & $100 \%$ & $100 \%$ & $100 \%$ & $100 \%$ & $100 \%$ & $100 \%$ \\
\hline \multicolumn{2}{|c|}{ Mean } & $98,01 \%$ & $98,81 \%$ & $97,87 \%$ & $99,79 \%$ & $96,31 \%$ & $97,89 \%$ \\
\hline
\end{tabular}

Dapat dilihat pada Tabel 2 diatas, bahwa tingkat efisiensi Bank Rakyat Indonesia Syariah (BRIS) selama periode penelitian, yaitu kuartal I 2016 sampai kuartal II 2019, mengalami fluktuatif dengan nilai rata-rata sebesar 98,01\%. Pada tahun 2016 yang merupakan awal tahun dimulainya MEA 2025, Bank Rakyat Indoneisa Syariah (BRIS) belum mencapai tingkat efisiensi optimum selama 4 kuartal atau setahun penuh, dengan nilai sebesar 93,55\% pada kuartal pertama, lalu pada periode berikutnya kuartal II 2016 mengalami peningkatan menjadi 95.33\%, dan kuartal III 2016 sayangnya mengalami penurunan menjadi 94,83\%, lalu meningkat kembali menjadi 99,72\%. Dan pada akhirnya pada awal tahun 2017 Bank Rakyat Indonesia Syariah (BRIS) mendapatkan nilai efisiensi optimum sampai dengan kuartal I 2017 hingga kuartal II 2017. Namun pada kuartal III 2017, Bank Rakyat Indoneisa Syariah (BRIS) kembali mengalami penurunan menjadi $95,2 \%$ dan menurun kembali menjadi 93.44\% pada kuartal IV 2017 yang merupakan periode dengan nilai efisiensi terendah yang didapatkan oleh Bank Rakyat Indoneisa Syariah (BRIS). Dan setelah itu, pada akhirnya mulai kuartal I 2018 sampai dengan akhir periode penelitian Bank Rakyat Indonesia Syariah (BRIS) mencapai tingkat efisiensi optimumnya kembali secara berturut-turut.

Berdasarkan penjelasan diatas menunjukan bahwa selama periode penelitian, Bank Rakyat Indoneisa Syariah (BRIS) dari awal mulainya MEA 2025 dan di beberapa periode selanjutnya belum dapat menjalankan fungsinya sebagai lembaga intermediasi secara optimal dan efisien sebanyak enam kali. Namun juga pada periode kuartal I 2017 dan kuartal II 2017 serta pada kuartal I 2018 sampai dengan kuartal II 2019 Bank Rakyat Indonesia Syariah (BRIS) telah menjalankan fungsinya sebagai lembaga intermediasi secara optimal dan efisien secara konsisten

Penyebab belum mencapainya tingkat efisiensi optimum pada Bank Rakyat Indonesia Syariah (BRIS), yaitu akibat dari adanya varibel input maupun output yang belum berkontribusi secara 
maksimal dalam mencapai tingkat efisiensi optimumnya. Pada kuartal I 2016 sampai dengan kuartal III 2016 mengalami penyebab yang sama, yaitu akibat dari adanya peningkatan pada Dana Pihak Ketiga (DPK) dan pemborosan pada Biaya Tenaga Kerja (BTK) yang tidak sebanding dengan peningkatan pada jumlah Pembiayaan dan Pendapatan Operasional yang dihasilkan. Sedangkan pada kuartal III dan IV 2017, disebabkan karena adanya peningkatan pada nilai Aset yang dimiliki tidak sebanding dengan peningkatan pada jumlah Pembiayaan dan Pendapatan Operasional yang didapat.

\subsection{Kebijakan yang Dapat Dilakukan Bank Umum Syariah}

Rekomendasi-rekomendasi yang dapat dilakukan Bank Umum Syariah, terutama pada Bank Umum Syariah yang belum mencapai tingkat efisiensi optimum, berdasarkan hasil perhitungan efisiensi dalam penelitian ini dengan menggunakan metode Data Envelopment Analysis (DEA). Pengukuran efisiensi dengan metode Data Envelopment Analysis (DEA) ini cenderung terbatas pada hubungan teknik dan operasional dalam proses konversi input menjadi output (Huda \& Nasution, 2014). Hal ini menyebabkan untuk meningkatkan tingkat efisiensi dapat dengan melakukan pengendalian dan alokasi sumber daya yang optimal.

Berdasarkan dari hasil perhitungan Data Envelopment Analysis (DEA) dengan menggunakan aplikasi Banxia Frontier Analysis, menunjukan bahwa rata-rata Bank Umum Syariah dalam penelitian ini berada dalam kondisi Increasing Return to Scale (IRS). Kondisi Increasing Return to Scale (IRS) ini menunjukan bahwa dengan penambahan input justru tidak akan efektif karena sumber daya yang digunakan masih belum berfungsi secara optimal sehingga mememungkinkan untuk Bank Umum Syariah dapat terus meninggkatkan kapasitas outputnya dengan mempertahankan input yang ada.

Penghimpunan Dana Pihak Ketiga tanpa disertai dengan penggunaan yang baik sehingga tidak dapat menghasilkan output yang optimal, dapat menjadi salah satu penyebab Bank Umum Syariah tidak mencapai tingkat efisiensi optimum. Meskipun penghimpunan Dana Pihak Ketiga yang berlebihi sebenarnya merupakan sebuah prestasi bahwa produk penghimpun dana yang dimiliki oleh Bank Umum Syariah tersebut diminati oleh masyarakat, namun hal tersebut tentunya harus diimbangi dengan penyaluran pembiayaan yang berkulitas (Anisa \& Tripuspitorini, 2019). Seperti yang dialami oleh Bank Negara Indonesia Syariah (BNIS) sebanyak 6 kali selama periode penelitian dan Bank Rakyat Indonesia Syariah (BRIS) yang dialami sebanyak 3 kali selama periode penelitian. Upaya yang dapat dilakukan, yaitu dengan meningkatkan jumlah penyaluran dana kepada produk-produk pembiayaan. Hal ini berarti dana yang terhimpun dari masyarakat berupa Dana Pihak Ketiga dapat disalurkan kembali ke masyarakat melalui pembiayaan, sesuai dengan fungsinya sebagai lembaga intermediasi. Adapun cara lainnya, yaitu dengan menaikkan biaya administrasi pada Dana Pihak Ketiga sehingga pendapatan operasional bank syariah pun sekaligus dapat diperbaiki, namun tentunya harus diiringi dengan peningkatan dalam kuliatas jasa pelayanan agar dapat tetap mampu bersaingan.

Pemborosan dalam mengeluarkan Biaya Tenaga Kerja tanpa disertai dengan hasil output yang optimal pun menjadi salah satu penyebab Bank Umum syariah belum dapat mencapai tingkat efisiensi optimum. Seperti yang dialami oleh Bank Negara Indonesia Syariah (BNIS) sebanyak 7 kali selama periode penelitian dan Bank Rakyat Indonesia Syariah (BRIS) yang dialami sebanyak 3 kali selama periode penelitian. Ketidak efisienan dalam Biaya Tenaga Kerja ini menjadi faktor dari sisi input yang sering dan terbesar menjadi penyebab Bank Umum Syariah tidak mencapai tingkat efisiensi optimum. Hal ini dapat diakbiatkan oleh adanya agresivitas Bank Umum Syariah dalam berekspansi. Ketika berekspansi, tentunya Bank Umum syariah membuka kantor cabang baru dan akhirnnya terjadinya peningkatan dalam sumber daya manusia sehingga tentunya diikuti dengan meningkatnya Biaya tenaga Kerja yang perlu dikerluarkan. Selain itu besarnya kebutuhan akan SDM bagi Bank Umum Syariah tidak sebanding dengan tersediaan SDM yang berkualitas sehingga 
dibutuhkan pendidikan dan pelatihan lebih lanjut sebelum siap untuk terjun ke lapangan. Kebijakan pemenuhan SDM bank umum syariah perlu ditingkatkan sehingga ketimpangan akan kebutuhan tenaga kerja dapat diatasi. Sejalan dengan salah satu program pada Roadmap Perbankan Syariah Indonesia, yaitu peningkatan kapasitas SDM dengan meningkatkan kualitas SDM yang ditujukan kepada seluruh pihak yang berperan aktif dalam pengembangan dan operasional keuangan syariah (Otoritas Jasa Keuangan, 2017). Hal ini akan sangat mempengaruhi upaya pengembangan bidang lainnya seperti pengembangan produk serta layanan sehingga akan meningkatkan kepercayaan para nasabah (Nurrohmah \& Purbayati, 2020). Hal yang dapat dilakukan yaitu dengan mendorong program link and match sehingga melalui kerja sama yang dilakukan oleh perguruan tinggi dan industri keuangan syariah ini, lulusan perguruan tinggi akan memenuhi kualifikasi yang sesuai dengan kebutuhan industri perbankan syariah (Otoritas Jasa Keuangan, 2017). Pada Laporan Perkembangan Keungan Syariah tahun 2018 juga memberikan rekomendasi dalam pengefisenan tenaga kerja dengan memiliki in-house training (IHT) dan memberi kesempatan kepada pegawai untuk menjadi pelatih/pengajar/trainer di beberapa program internal sehingga dapat menekan biaya penggunaan jasa pelatih/pengajar/trainer eksternal atau vendor, atau dengan pemanfaatan e-learning untuk materi pembelajaran tidak memerlukan diskusi tatap muka, dinilai jauh lebih efisien dan fleksibel dibandingkan dengan pembelajaran dalam kelas. Selain itu inovasi digitalisasi perbankan juga dapat mengurangi kegiatan operasional yang dilakukan secara manual atau dengan melakukan model shared service. Hal lain yang dapat dilakukan adalah dengan penghematan akan Biaya Tenaga Kerja yang dikeluarkan untuk para direksi atau dengan penghematan pada pemberian tunjungan-tujungan (Otoritas Jasa Keuangan, 2018).

Selain Dana Pihak Ketiga dan Biaya Tenanga Kerja, Aset yang merupakan variabel input pun dapat menjadi salah satu penyebab Bank Umum syariah blum dapat mencapai tingkat efisiensi optimum. Hal ini akibat dari besarnya Aset yang dimiliki tanpa diimbangi dengan hasil output yang optimal. Seperti yang dialami oleh Bank Negara Indonesia Syariah (BNIS) dan Bank Rakyat Indonesia Syariah (BRIS) yang dialami sebanyak 2 kali selama periode penelitian. Upaya yang dapat dilakukan, yaitu dengan memperbaiki dalam pengelolaaan alokasi jumlah total aset yang dimiliki bank syariah dengan memperbesar pengalokasian porsi aset produktif berupa pembiayaan yang merupakan bagian dari aset total sendiri. Nilai pembiayaan yang semakin besar akan memperlancar proses intermediasi bank syariah dan sekaligus dapat memperbaiki pendapatan operasional.

Selain pada veriabel input, berdasarkan dari hasil penelitian ini juga menunjukan bahwa ketidak tercapainya tingkat efisiensi optimum selalu diikuti oleh ketidak optimalan pada variable outputnya, yaiitu pada pembiayaan dan pendapatan operasional. Seperti yang dialami oleh Bank Negara Indonesia Syariah (BNIS) dan Bank Rakyat Indonesia Syariah (BRIS) di setiap periode yang masih belum mencapai tingkat efisiensi optimumnya. Hal ini diakbitakan oleh belum tercapainya pembiyaan maupun pendapatan operasional dengan terget untuk mencapai tingkat efisiensi optimum. Maka dari itu hal yang dapat dilakaukan adalah dengan menambah pada jumlah pembiayaan maupun pendapatan operasional.

Pembiayaan yang belum efisien artinya Bank Umum Syariah tersebut belum optimal dalam menyeluarkan dananya berupa pembiyaan. Salah satu penyebabnya, yaitu dapat berupa dari adanya berlebihannya pada prinsip kehati-hatian yang dijalankan oleh Bank Umum Syariah tersebut sehingga penerapan prinsipnya menghambat pencapaian target jumlah pembiayaan yang seharusnya dilakukan. Solusi dari permasalahan ini adalah penerapan prinsip kehati-hatian yang ada tidak menjadikan jumlah pembiayaan terhambat atau seperti kebijakan yang direkomendasikan pada Masterplan Asitektur Keuangan Syariah, yaitu dengan mengizinkan rasio pembiayaan terhadap agunan yang lebih tinggi untuk produk pembiayaan terpilih (BAPPENAS, 
2016). Hal tersebut tentunya harus memerlukan pengawasan yang lebih ketat dalam pencegah terjadinya moral hazard sehingga output pembiayaan pun dapat lebih optimal. Selalin itu yang dapat dilakukan, yaitu dengan inovasi-inovasi pada produk pembiayaan maupun pelayanan dengan ditambahnya dengan melakukan pemasaran-pemasaran yang menarik dan mudah dipahami oleh masyarakat agar para nasabah maupun calon nasabah dapat mengetahui lalu tertarik serta yakin dengan produk-produk dari Bank Umum Syariah terutama untuk para nasabah rasional, karena pengunaan suatu produk keuangan syariah oleh masyarakat sangat dipengaruhi oleh tingkat pemahaman masyarakat terhadap fungsi, jenis, dan karakteristik dari produk keuangan syariah tersebut (Otoritas Jasa Keuangan, 2017). Hal tersebut sejalan dengan misi pada Roadmap Keuangan Syariah Indonesia, yaitu memperluas akses terhadap produk dan layanan keungan syariah untuk memenuhi kebutuhan masyarakat, seperti dengan menambah variasi produk pembiayaan mikro, dan mengembangkan produk pembiayaan korporasi, start up financing, produk pengelolaan kas dan/atau fund management, trade finance, serta produk-produk development financing khususnya untukkpembangunan infrastruktur (Otoritas Jasa Keuangan, 2017).

Denagn meningkatnya jumlah pembiyaan maka pendapatan operasional yang massih belum mencapai potensinya dapat ikut meningkat pula. Namun perlu perhatikan juga bahwa peningkatan pembiayaan juga akan menaikan resiko pembiayan oleh karena itu perlu juga adanya monitoring terhadap kualitas pembiayaan serta pemantauan dan penyelesaian terhadap debitur bermasalah. Pendapatan operasional juga dapat ditingkatkan dengan mengurangi cost of fund berupa menaikan dana murah yang dimiliki bank umum syariah sehingga pendapatan yang berasal dari penyaluran dana tidak tergerus oleh cost of fund yang tinggi. Selain itu juga bisa dengan memperbesar porsi jumlah aset produktif dari total aset yang dimiliki, optimalisasi peran pembiayaan denagn mengurangi Non Performing Financing (NPF) dan aktiva tetap, perbaikan kualitas dan kuantitas pelayanan jasa serta SDM juga dapat meningkatkan pendapatan operasional, karena ini berkaitan dengan produktifitas tenaga kerja dalam mengelola input yang ada untuk menghasilkan otput yang optimal.

\section{Penutup}

Penelitian ini bertujuan untuk mengidentifikasi tingkat efisiensi Bank Umum Syariah dan kebijakan yang dapat dilakukan Bank Umum Syariah dalam meningkatkan efisiensinya dengan menggunakan metode Data Envelopment Analysis (DEA) dan model Variable Return to Scale (VRS) dengan pendekatan intermediasi. Penelitian ini menggunakan 6 (Enam) Bank Umum Syariah Devisa sebagai sampelnya. Berdasarkan hasil analisis yang telah penulis lakukan, maka dapat ditarik kesimpulan, bahwa selama periode penelitian mulai dari kuartal I 2016 sampai dengan kuartal II 2019, di era Masyarakat Ekonomi ASEAN (MEA), Bank Umum Syariah di Indonesia yang menjadi sampel dalam penelitian ini menunjukan bahwa rata-rata keseluruhan tingkat efisiensinya sudah dikategorikan cukup baik dan hampir mencapai tingkat efisiensi optimum, yaitu sebesar 99,15\% yang artinya bahwa sebagian besar Bank Umum Syariah selama periode penelitian telah cukup baik dalam menjalankan perannya sebagai lembaga intermediasi. Bank Umum Syariah yang selalu mencapai tingkat efisiensi optimum dengan nilai sebesar 100\% secara konsisten atau berturut-turut adalah Bank Muamalat Indonesia (BMI), Bank Mega Syariah (BMS), Bank Syariah Mandiri (BSM), dan Bank Panin Dubai Syariah (PNBS). Sedangkan Bank Umum Syariah yang mengalami fluktuasi pada tingkat efisiensinya adalah Bank Negara Indonesia Syariah (BNIS) dan Bank Rakyat Indonesia Syariah (BRIS), dengan nilai efisiensi terendah dimiliki oleh Bank Negara Indonesia (BNIS), yaitu sebensar $93.09 \%$. Penyebab Bank Umum syariah yang belum mencapai tingkat efisiensi optimum, yaitu akibat dari adanya varibel input maupun output yang belum berkontribusi secara maksimal dalam mencapai tingkat efisiensi optimumnya. 
Rekomendasi-rekomendasi kebijakan yang dapat dilakukan Bank Umum Syariah, terutama bagi Bank Umum Syariah yang belum mencapai tingkat efisiensi optimum, untuk meningkatkan tingkat efisiensinya adalah dengan melakukan pengendalian dan alokasi sumber daya yang optimal. Selain itu, secara rata-rata Bank Umum Syariah mengalami kondisi Increasing Return to Scale (IRS) sehingga yang dapat dilakukan Bank Umum Syariah, yaitu dengan lebih meningkatkan kapasitas outputnya dengan mempertahankan input yang ada karena dengan penambahan input justru tidak akan efektif karena sumber daya yang digunakan masih belum berfungsi secara optimal.

Berdasarkan hasil penelitian dan kesimpulan yang telah dipaparkan sebelumnya, berikut adalah beberapa saran yang dapat penulis berikan dalam penelitian ini, yaitu :

1. Bagi Bank Umum Syariah, diharapkan dapat menggunakan penelitian ini sebagai salah satu bahan evaluasi bagi Bank Umum Syariah agar dapat terus meningkatkan dan mempertahannya tingkat efisiensinya sehingga dapat mampu bertahan dan bersaing di era Masyarakat Ekonomi ASEAN (MEA) dengan memaksimalkan kontribusi dari setiap variabel input maupun output agar dapat mencapai tingkat efisiensi optimal.

2. Selain itu bagi Bank Umum Syariah maupun para regulator, diharapkan penelitian ini dapat menjadi salah satu bahan pertimbangan untuk membuat kebijakan berdasarkan rekomedasi-rekomendasi kebijakan yang telah dikemukakan dalam penelitian ini.

3. Bagi peneliti selanjutnya diharapkan dapat mengembangkan penelitian ini, seperti dengan menambahkan rentang waktu periode penelitian dan/atau memperluas objek penelitian, atau juga dapat dengan melakukan perbandingan efisiensi Bank Umum Syariah di Indonesia dengan Bank Umum Syariah di negara-negara ASEAN lainnya sehingga dapat menunjukan bagaimana peluang Bank Umum Syariah indonesia di ASEAN. Selain itu, peneliti ini memiliki keterbatasan untuk mengetahui faktor apa saja yang memengaruhi nilai tingkat efisiensi pada Bank Umum Syariah, maka bagi peneliti selanjutnya dapat menambahkan pembahasan mengenai faktor-faktor yang dapat memengaruhi tingkat efisiensi pada Bank Umum Syariah sehingga dapat menghasilkan rekomendasi-rekomendasi kebijakan yang lebih luas.

\section{Daftar Pustaka}

ASEAN. (2019). Asean 2025: Forging Ahead Together. In Statistical Field Theor (Vol. 53, Nomor 9). https://doi.org/10.1017/CBO9781107415324.004

Anisa, L. S., \& Tripuspitorini, F. A. (2019). Analisis Pengaruh Dana Pihak Ketiga, Non Performing Finance Murabahah, dan Inflasi terhadap Pembiayaan Murabahah pada Bank Umum Syariah di Indonesia. Jurnal Kajian Akuntansi, 3(1), 52-64.

BAPPENAS. (2016). Masterplan arsitektur keuangan syariah Indonesia. BAPPENAS.

Fauziah, S. I., Sunarya, E., \& Komariah, K. (2019). Analisis Efisiensi dengan Menggunakan Metode Data Envelopment Analysis pada Bank Umum Syariah. JOMB: Journal of Management and Bussines, 1(1), 120-130. https://doi.org/https://doi.org/10.31539/jomb.v1i1.615

GIFR. (2019). Global Islamic Finance Report 2019. http://www.gifr.net/publications/gifr2019/ifci.pdf

Huda, N., \& Nasution, M. E. (2014). Current Issues Lembaga Keuangan Syariah. Kencana.

Hijriyani, N. Z., \& Setiawan, S. (2017). Analisis Profitabilitas Perbankan Syariah di Indonesia sebagai Dampak Dari Efisiensi Operasional. Jurnal Kajian Akuntansi, 1(2), 194-209 . 
Kamarudin, F., Sufian, F., Nassir, A. M., Anwar, N. A. M., \& Hussain, H. I. (2019). Bank Efficiency in Malaysia a DEA Approach. Journal of Central Banking Theory and Practice, 8(1), 133-162. https://doi.org/10.2478/jcbtp-2019-0007

Karimah, S., Novianti, T., \& Effendi, J. (2016). Kajian Efisiensi Bank Umum Syariah di Indonesia. Al-Muzara'ah, 4(1), 33-43. https://doi.org/10.29244/jam.4.1.33-43

KBBI. (n.d.). efisiensi. https://kbbi.web.id/efisiensi

Kusumo, W. K., \& Karim, A. (2017). PENGEMBANGAN MODEL PARAMETRIK METODE DEA DALAM MENGUKUR TINGKAT EFISIENSI BIAYA PADA PERBANKAN SYARIAH DI KOTA SEMARANG. Jurnal Dinamika Sosial Budaya, 19(1), 148-162.

Nurrohmah, R. F., \& Purbayati, R. (2020). Pengaruh Tingkat Literasi Keuangan Syariah dan Kepercayaan Masyarakat terhadap Minat Menabung di Bank Syariah. Jurnal Maps, 3(2), 140 153.

Otoritas Jasa Keuangan. (2017). Roadmap Pengembangan Keuangan Syariah 2017-2019. Otoritas Jasa Kenangan, 1-82. https://www.ojk.go.id/id/kanal/syariah/berita-dankegiatan/publikasi/Documents/Pages/Roadmap-Pengembangan-Keuangan-SyariahIndonesia-2017-2019/Roadmap 2017-2019(1).pdf

Otoritas Jasa Keuangan. (2018). Laporan Perkembangan Keuangan Syariah Indonesia. Ojk, 1-106.

Puspitasari, A., Purnomo, D., \& Triyono, T. (2018). Penggunaan Data Envelopment Analysis (DEA) dalam Pengukuran Efisiensi Bank Umum Syari'ah di Indonesia. BISNIS : Jurnal Bisnis dan Manajemen Islam, 5(2), 293. https://doi.org/10.21043/bisnis.v5i2.3015

Puteh, A., Rasyidin, M., \& Mawaddah, N. (2018). Islamic Banks in Indonesia: Analysis of Efficiency. 1, 331-336. https://doi.org/10.1108/978-1-78756-793-1-00062

Rusydiana, A. S. (2019). Efisiensi Sosial Dan Finansial Bank Syariah Di Indonesia: Pendekatan Nonparametrik. Riset Akuntansi dan Keuangan Indonesia, 4(1), 13-24. https://doi.org/10.23917/reaksi.v4i1.6814

Setyowati, D. H. (2019). Pengaruh Efisiensi Operasional Terhadap Return on Assets Pada Bank Umum Syariah Di Indonesia. Masharif al-Syariah: Jurnal Ekonomi dan Perbankan Syariah, 4(2), 39-53.

Soemitra, A. (2015). Bank dan Lembaga Kenangan Syariah. Prenadamedia Group.

Solihin, S., Achsani, N. A., \& Saptono, I. T. (2016). the Islamic Banking and the Economic Integration in Asean. Buletin Ekonomi Moneter dan Perbankan, 19(1), 81-106. https://doi.org/10.21098/bemp.v19i1.601

Tanjung, H., \& Devi, A. (2018). Metodologi Penelitian Ekonomi Islam. Gramata Publishing. 